Jurnal Ilmu Keolahragaan Volume III Nomor 1 Mei 2020

Grafitte Decheline

Tersedia di: http://jurnal.untan.ac.id/index.php/jilo

\title{
ANALISIS KEBUTUHAN BUKU SEBAGAI MEDIA PEMBELAJARAN ANATOMI OLAHRAGA UNTUK MAHASISWA FIK UNJA
}

\author{
Grafitte Decheline
}

Fakultas Ilmu Keolahragaan Univesitas Negeri Jambi

Email: grafiti@unja.ac.id

\begin{abstract}
Abstrak
Tujuan penelitian ini adalah untuk menganalisis kebutuhan yang diperlukan oleh mahasiswa dalam proses belajar mengajar mata kuliah Anatomi Olahraga. Kedua dilakukan penyusunan buku untuk perkuliahan anatomi. Sampel penelitian 51 mahasiswa, yang diangket dua kali, pertama tentang analisis kebutuhan kedua tentang isi dari buku yang telah disusun. Angket diberikan secara langsung dan menggunakan media google form. Hasil penelitian bardasarkan angket analisis kebutuhan disimpulkan diperlukan adanya buku sebagai pedoman untuk belajar matakuliah anatomi olahraga. Selanjutnya disusun buku anatomi yang dapat dipergunakan untuk perkuliahan. Berdasarkan angket yang kedua terhadap bahan kuliah yang telah disusun menyimpulkan bahwa buku yang dipergunakan menarik, dapat dipahami dan diperguakan untuk perkuliahan.
\end{abstract}

Kata kunci: Anatomi Olahraga, Buku

\section{ANALYSIS OF BOOK NEEDS AS A MEDIA OF SPORTS ANATOMY LEARNING FOR FIK UNJA STUDENTS}

\begin{abstract}
Research aimed to analyze student needs in the teaching and learning process of Sports Anatomy. Second were the compilation of books for anatomy lectures. Research sample 51 students, which twice researched, first about the analysis of needs, second about the contents of the books that have been compiled. Questionnaire given directly and Google form. The results of the study based on the needs analysis questionnaire concluded that a book was needed as a guide for learning sports anatomy courses. Furthermore, anatomy books can be prepared that can be used for lectures. Based on the second questionnaire on the lecture material that has been compiled concluded that the book used interested, understand able and used for lectures.
\end{abstract}

Keywords: Sport anatomi, Books 
Jurnal Ilmu Keolahragaan Volume III Nomor 1 Mei 2020

Grafitte Decheline

Tersedia di: http://jurnal.untan.ac.id/index.php/jilo

\section{PENDAHULUAN}

Salah satu mata kuliah wajib yang harus diambil oleh Mahasiswa di Fakultas Ilmu Keolahragaan baik dari prodi Kepelatihan Olahraga maupun di prodi PORKES yaitu Anatomi. Lorena Martin (2016) Pemahaman terhadap dasar dasar anatomy dan fisiologi merupakan dasar untuk memberikan pemahaman yang menyeluruh bagi atlet. Mahasiswa kepelatihan adalah mahasiswa yang dididik untuk menjadi pelatih bagi atlet, sehingga pemahaman sebagai pelatih harus lebih tinggi dibandingkan dengan atlet. Penguasaan mata kuliah ini dirasakan sangat berat, karena diperlukan berbagai sarana yang mestinya disediakan, saat ini, buku ajar yang tersedi hanya slide Powerpoint yang ditayangkan saat perkuliahan. Terdapat buku yang dijadikan pegangan, namun buku tersebut bukan buku pegangan hasil karya dosen yang bersangkutan. Slide PowerPoint terkadang tidak banyak mencakup materi untuk dimengerti sepenuhnya oleh mahasiswa. Ketidaktersediaan buku ajar seperti buku ajar anatomi menyebabkan mahasiswa kesulitan untuk dapat belajar secara mandiri dan terarah pada pencapaian pembelajaran, karena hanya bergantung pada penyampaian materi saat tatap muka sementara Slide tidak dapat dipelajari sendiri.

Lorena Martin (2016) anatomi dan fisiologi mempelajari tentang tulang, otot, sisten energy, persendian dan system dalam tubuh manusia. Khusus anatomi diperlukan kemampuan menghafal bagaian bagian tulang, otot dan sendi dengan bahasa latin ataupun bahasa inggris

Fungsi dari materi kuliah Anatomi Olahraga ini adalah untuk memberikan bekal dasar yang essential kepada mahasiswa, dimana kegiatan olahraga adalah menggerakan tubuh manusia secara sistematis dengan fungsi fungsi dalam sistem tubuh. tidak akan pernah.

Mahasiswa sebagai calon pelatih memerlukan pemahaman yang mendalam tentang anatomi dan fisiologi manusia. Anatomi sebagai pengetahuan dan pemahaman struktur tubuh manusia terutama tentang gerak dan keterbatasannya, fisiologi tentang bagaimana sistem tubuh dengan organ organnya mendukung untuk bergerak.

Penelitian plyometric dapat meningkatkan kebugaran, terjadi pada olahraga open skill dan komplek skill termasuk dalam olahraga tim (Chaouachi et al., 2009; Duncan et al., 2006; Gabbett, 2000; Ostojic et al., 2006; Stolen et al., 2005). Soccer, basketball, handball and rugby merupakan contoh olahrga beregu yang menggabungkan gerak siklis dan asiklis selama bergerak untuk keberhasilan bermain, (Arazi et al., 2012; Chelly et al., 2014; Stolen et al., 2005).

Paragraf di atas memberikan gambaran aplikasi dari pemahaman anatomi dan fisiologi, ketika pelatih memahami tentang system energy, intensitas kerja dan bagaimana orang harus bergerak maka dapat dilakukan penelitian kaitannya plyometric (intensitas tinggi, system energy an aerob), kinerja tinggi (jantung, paru, otot, tulang dan persendian) sebagai pengaruh intensitas.

Dengan demikian, diperlukan pemahaman yang baik minimal tentang tubuh kita sendiri sebelum kita melakukan olahraga. Bagian-bagian tubuh mana yang akan kita latih, mana yang dapat dilatih, mana yang tidak dapat dilatih, kemudian olahraga atau aktivitas olahraga apa yang cocok untuk melatihh beberapa bagian tubuh yang kita inginkan.

Diperlukan berbagai macam referensi untuk dapat membantu pemahaman mahasiswa. Terdapat berbagai buku yang dapat digunakan sebagai referensi, seperti 


\section{Jurnal Ilmu Keolahragaan Volume III Nomor 1 Mei 2020 \\ Grafitte Decheline \\ Tersedia di: http://jurnal.untan.ac.id/index.php/jilo}

Sobotta yang biasa digunakan oleh mahasiswa kedokteran untuk menganalisa anatomi tubuh manusia. Namun mahasiswa Olahraga sulit untuk mendapatkan referensi tersebut, selain karena harga yang mahal, berbagai pertimbangan kemudian banyak muncul menjadi kendala dalam pengadaan referensi Sobotta

\section{METODE}

Penelitian ini merupakan penelitian kuantitatif dengan digunakan teknik survei yang akan diberikan kepada sampel. Sampel dalam penelitian ini adalah 51 orang mahasiswa di Fakultas Ilmu Keolahragaan Universitas Jambi Tahun 2019 prodi kepelatihan olahraga. Angket diberikan dengan menggunakan angket print out di kerjas dan google form. Angket yang diberikan adalah angket tertutup. Berdasarkan hasil angket tersebut kemudian disusun buku ajar untuk mata kuliah anatomi dan pada akhir semester diberikan angket kaitan dengan buku ajar yang disusun dan dipergunakan untuk perkuliahan.

\section{HASIL}

Kuesioner yang diberikan kepada para responden melalui diketahui bahwa beberapa pernyataan yang diajukan kepada responden merujuk pada kebutuhan buku sebagai media pembelajaran. Angket yang diberikan selan berupa cetak atau angket berjalan, namun juga melalui Google Form seperti gambar dibawah ini: apakah mata kuliah anatomi sulit?

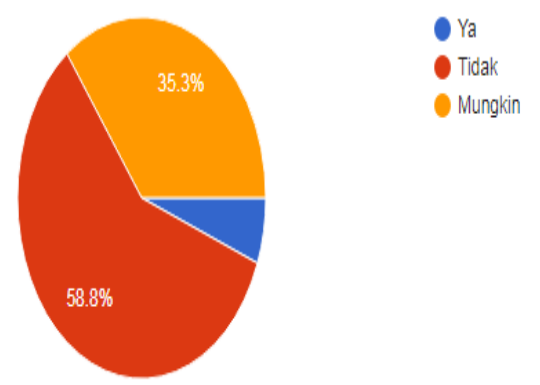

\section{Grafik 1. Hasil pendapat tentang kesulitan matakuliah anatomi}

Berdasarkan pada grafik di atas dinyatakan bahwa anatomi $35,6 \%$ menyatakan mata kuliah yang tidak sulit dan sisanya masih menebak nebak dengan jawaban mungkin.

apakah yang anda butuhkan untuk sumber belajar?

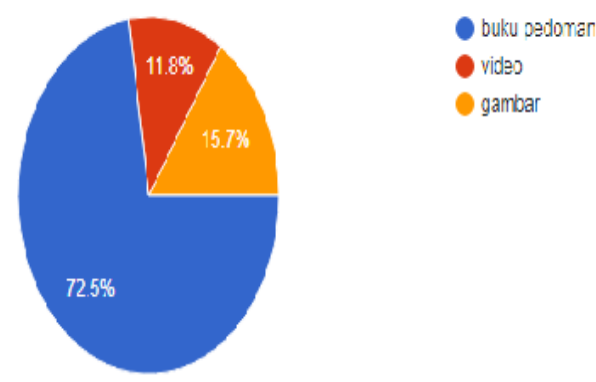

Grafik 2. Hasil Kebutuhan Sumber Ajar

Berdasarkan pada pertanyaan mengenai kebutuhan sumber belajar, mahasiswa menjawab $72,5 \%$ adalah buku pedoman belajar, selebihnya tentang vidio dan gambar hanya kisaran 11 dan 15\% 

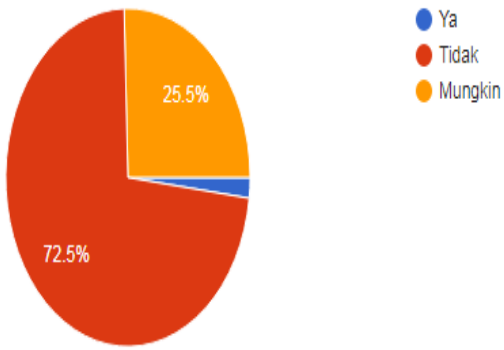

\section{Grafik 3. Hasil Suasana Belajar}

\section{Anatomi}

Dilihat dari hasil angket dapat diketahui bahwa sebenarnya mahasiswa antosias belajar mata kuliah ini, hal ini dibuktikan dengan $72.5 \%$ mahasiswa tidak mengantuk di kelas dan hanya kurang dari $4 \%$ yang mengantuk.

\section{apakah anda mengerti dengan materi yang disampaikan?}

53 responses

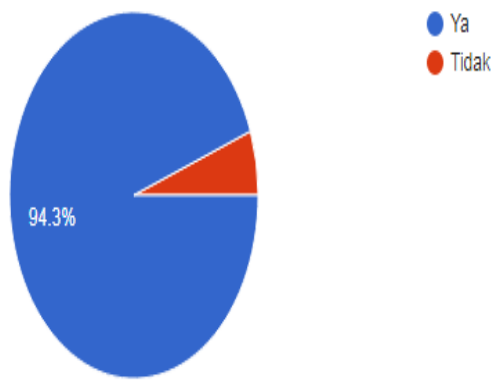

\section{Grafik 4. Hasil pemahaman belajar}

Berdasarkan pada jawaban di atas dinyatakan bahwa mahasiswa sebagai sampel mengerti materi yang disampaikan.

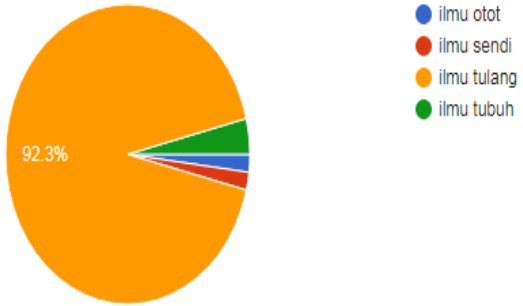

Grafik 5. Hasil Kuesioner Kebutuhan Buku ajar

Berdasarkan hasil kuesioner yang telah diisi oleh mahasiswa sebanyak 72,5 $\%$ mahasiswa mengatakan membutuhkan buku sebagai pegangan mereka dalam perkuliahan anatomi. Sebanyak 5,9 \% mahasiswa masih mengatakan bahwa anatomi adalah yang sulit. Hal ini menunjukkan bahwa pembuatan buku ajar atau ajar untuk belajar sangat dibutuhkan.

Buku yang digunakan sebagai pegangan harus mencakup keseluruhan aspek yang diajarkan kepada mahasiswa dengan baik. Seperti buku yang dilengkapi dengan gambar, karena dalam menghafal letak dan bagian-bagian tubuh, mahasiswa juga harus mengetahui secara pasti lewat melihat. Visualisasi akan lebih terasa seperti nyata daripada hanya membayangkan letak bagianbagian tersebut saja.

Mengerti dan mengetahui bagianbagain tubuh mungkin adalah pelajaran yang mudah, karena dpat dihapalkan dengan baik oleh mahasiswa, namun dari segi pemahaman, belum tentu signifikan. Hal ini dikarenakan banyak mahasiswa yang mengetahui bagian-bagian tubuh namun kurang paham bagian tubuh tersebut berhubungan dengan bagian tubuh yang mana saja dan bagaimana dia bisa bergerak, bagaimana cara melatih dan resiko cedera yang dapat terjadi di 


\section{Jurnal Ilmu Keolahragaan Volume III Nomor 1 Mei 2020 \\ Grafitte Decheline \\ Tersedia di: http://jurnal.untan.ac.id/index.php/jilo}

bagian tersebut. Pemahaman bagian tubuh untuk bergerak inilah yang sebenarnya merupakan dasar utama tujua pembelajaran Anatomi Olahraga diberikan.

Berdasarkan hasil angket tentang pemahaman sementera mahasiswa terhadap kuliah anatomi, kemudian disusun buku anatomi untuk perkuliahan. Buku ini kemudian diberikan kepada mahasiswa untuk proses belajar mengajar. Buku tersebut mencakup materi-materi dasar yang akan diberikan kepada mahasiswa. Selain itu, di dalam buku tersebut juga diberikan gambar visual tentang bagian-bagian tubuh beserta dengan nama latin nya agar dapat dihafalkan dan di pahami oleh mahasiswa. Setelah buku selesai dibuat, maka responden dalam penelitian ini diminta untuk merespon dan mengomentari bagaimana buku yang sudah jadi tersebut. apakan menurut anda buku inI cukup menarl|k untuk aldaca'?

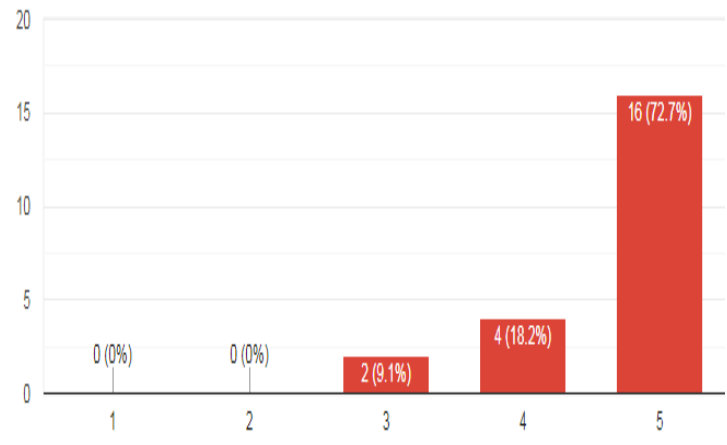

\section{Gambar 2. Angket Menariknya Buku}

\section{Keterangan :}

Poin 1 = sangat tidak menarik,

$2=$ kurang menarik,

$3=$ cukup menarik,

$4=$ menarik,

$5=$ sangat menarik
Di dalam grafik diatas, tergambarkan bahwa sebesar $72.7 \%$ atau sekitar 45 responden dari seluruh responden yang ada mengatakan bahwa buku ini sangat menarik.

\section{apakah anda mengerti tentang isi Buku ini?}

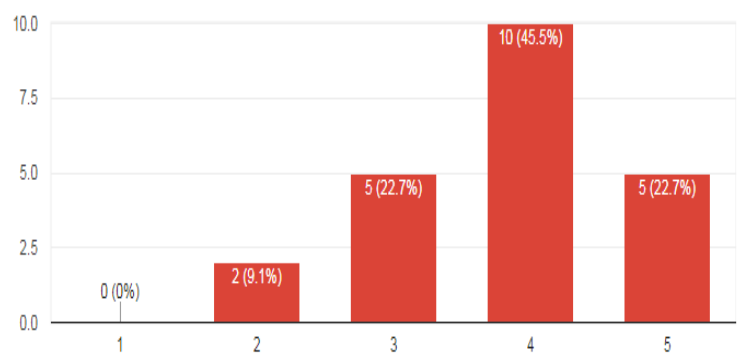

Gambar 3. Angket Pemahaman Buku

\section{Keterangan :}

Poin 1 = sangat tidak mengerti, $2=$ kurang mengerti, $3=$ cukup mengerti, $4=$ mengerti, $5=$ sangat mengerti

Di dalam grafik diatas, tergambarkan bahwa sebesar $45.5 \%$ atau sekitar 33 responden dari seluruh responden yang ada mengatakan bahwa mereka dapat mengerti tetang isi buku dan pembahasan yang ada di dalam buku tersebut. 


\section{Jurnal Ilmu Keolahragaan Volume III Nomor 1 Mei 2020 Grafitte Decheline \\ Tersedia di: http://jurnal.untan.ac.id/index.php/jilo}

apakah anda akan menggunakan buku ini sebagai rujukan/referensi dikemudian hari?

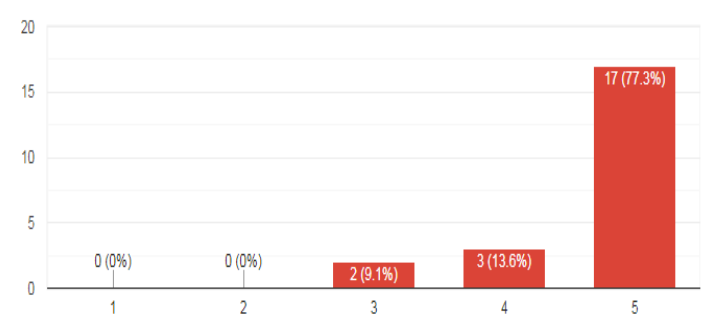

Gambar 4. Angket Penggunaan Buku Sebagai Referensi

Keterangan :

Poin 1 = sangat tidak akan saya gunakan, $2=$ tidak tahu,

$3=$ mungkin tidak akan digunakan,

$4=$ mungkin akan digunakan,

$5=$ ya, akan saya gunakan

Pada gambar 4 tergambarkan bahwa sebesar $77.3 \%$ atau sekitar 47 responden seluruh responden yang ada mengatakan bahwa buku ini akan mereka gunakan sebagai referensi dikemudian hari.

Berdasarkan dengan jawaban pernyataan kuesioner yang diberikan kepada responden, sebagian besar responden menyatakan bahwa mereka setuju dengan adanya buku yang diterbitkan sebagai pedoman pemelajaran Mata Kuliah Anatomi Olahraga mereka di Kampus. Hal ini yang memberikan penguatan bahwa mahasiswa sangat membutuhkan buku sebagai pedoma belajar mereka. Selain itu, buku juga dapat digunakan sebagai referensi mereka dalam pembelajaran selanjutnya.

Buku yang dikeluarkan diharapkan dapat memfasilitasi pemahaman mahasiswa yang lebih mendalam tentang mata kuliah Anatomi Olahraga. Sehingga Analisis kebutuhan tentang Buku sebagai Media pembelajaran Mahasiswa di FIK UNJA memang sangat diperlukan dengan rata-rata kebutuhan $70 \%$.

\section{PEMBAHASAN}

Briggs (1977) dalam Fathan (2019) media pembelajaran adalah sarana fisik untuk menyampaikan isi/materi pembelajaran seperti: buku, film, video, dan sebagainya. Selain itu, menurut National Education Association (1969) menyatakan bahwa media pembelahran adalah sarana komunikasi dalam bentuk cetak maupun pandang-dengar termask teknologi perangkat keras. Menurut Edgar Dale, dalam dunis Pendidikan, penggunaan media pembelajaran seringkali menggunakan prinsip Kerucut Pengalaman, yang membutuhkan media seperti buku teks, bahan belajar yang dibuat oleh guru, dan "audio-visual".

Gambar: Kerucut Pengalaman Edgar Dale

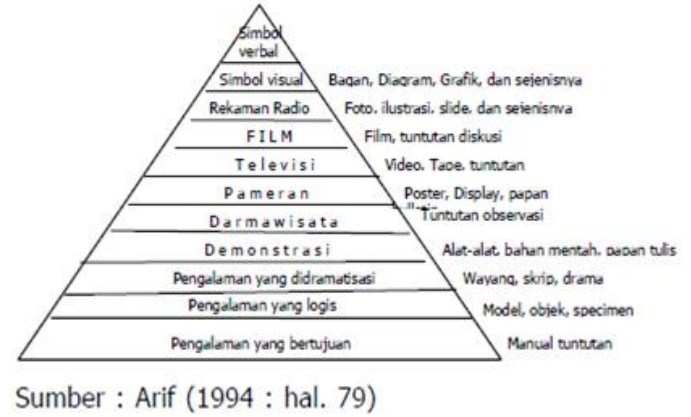

\section{Gambar 5. Kerucut Pengalaman} Edgar Dale

Penggunaa media pembelajaran untuk diterapkan kepada siswa/mahasiswa adalah untuk memberi kemudahan pada saat pembelajaran. Sama halnya dengan yang dikemukakan oleh Hamalik (1986) dalam Azhar (2000), yang mengemukakan bahwa pemakaian media pengajaran dalam proses belajar mengajar dapat membangkitkan keinginan dan minat yang baru, membangkitkan motivasi dan rangsangan kegiatan belajar, dan bahkan membawa pengaruhpengaruh sikologis terhadap siswa. 


\section{Jurnal Ilmu Keolahragaan Volume III Nomor 1 Mei 2020 Grafitte Decheline \\ Tersedia di: http://jurnal.untan.ac.id/index.php/jilo}

Berikut beberapa manfaat media dalam pembelajaran secara rinci menurut Kemp dan Dayton (1985), yaitu:

1. Penyampaian materi pelajaran dapat diseragamkan

2. Proses pembelajaran menjadi lebih interaktif

3. Proses pembelajaran menjadi lebih jelas dan menarik

4. Efisiensi dalam waktu dan tenaga

5. Meningkatkan kualitas hasil belajar siswa

6. Media memungkinkan proses belajar dapat dilakkukan diman saja dan kapan saja

7. Media dapat menumbuhkan sikap positif siswa terhadap materi proses belajar

8. Merubah peran guru ke arah yang lebih positif dan produktif

Adanya insight yang timbul karena penggunaan media pengajaran sangat diperlukan, hal ini bertujuan untuk menimbulkan rasa ingin tahu dan pemahaman yang baik dari siswa agar tercipta pembelajaran yang lebih kondusif.

Dalam mata kuliah Anatomi terdapat beberapa materi yang harus dikuasai oleh mahasiswa, diantaranya Sitologi (ilmu tentang sel), Histologi (ilmu tentang jaringan), Osteologi (ilmu tentang tulang), Myologi (ilmu tentang otot), Arthrologi (ilmu tentang sendi), dan sebagainya. Beberapa materi terlihat tidak terlalu rumit karena pernah diberikan kepada siswa di bangku sekolah (SMA).

Namun, beberapa materi dapat dikatakan sulit dikarenakan mereka harus dapat menghafal nama-nama latin bagianbagian tubuh. Seperti pada materi osteologi, mahasiswa diharapkan mampuu menunjuk dan menyebutkan nama bagian tulang seperti ossa. coxae (tulang panggung), atau ossa. cubiti (tulang siku), ossa. frontale (tengkorak kepala), dan lain sebagainya. Selain itu, pada materi myologi dan arthrology, mahasiswa lebih sulit untuk mengetahui letak bagian-bagian otot dan sendi dalam tubuh.

Berbagai kendala ini lah yang difasilitasi oleh dosen sebagai fasilitator pembelajaran. Menyediakan fasilitas pengajaran yang baik untuk mahasiswa dengan materi yang terpecaya dan dapat digunakan mahasiswa sebagai referensi. Buku diharapkan dapat dijadikan pedoman dan sumber penunjang dalam perkuliahan mata kuliah Anatomi Olahraga, terkhusus di Fakultas Ilmu Keolahragaan yang masih minim dengan sumber-sumber bacaan untuk mahasiswa.

Apalagi di era yang serba canggih seperti saat ini, buku sering dilupakan sebagai media referensi cetak yang paling akurat dari pada bacaan artikel atau online yang harus dicari tahu lebih mendalam tentang kebenaran informasi yang tersedia tersebut.

Dosen sebagai fasilitator pembelajaran juga dituntut untuk dapat lebih kreatif dan produktif dalam pemberian materi kepada mahasiswa. Berdasarkan Workshop Kegiatan Penulisan Buku ajar Mahasiswa di Auditorium LP3M yang dilakukan oleh UNESA, Kepala Pusat Pengembangan juga menegaskan bahwa sebagai pengajar, dosen harus selalu mengembangkan pembelajaran yang didukung dengan kualitas bahan ajar untuk mahasiswa.

\section{KESIMPULAN}

Berdasarkan pada angket penelitian pendahuluan disimpulkan diperlukan buku pedoman demi kelancaran proses belajar mata kuliah atanomi. Pada bagian kedua disusun buku untuk mata kuliah anatomi, setelah tersusun buku kemudian diberikan kepada mahasiswa dan setelah proses pembelajaran berakhir menyatakan 


\section{Jurnal Ilmu Keolahragaan Volume III Nomor 1 Mei 2020 Grafitte Decheline \\ Tersedia di: http://jurnal.untan.ac.id/index.php/jilo}

bahwa buku yang disusun menarik, dapat dipahami dan diperguakan untuk perkuliahan, yang diperuntukkan kepada Mahasiswa di Fakultas Ilmu Keolahragaan Universitas Jambi, baik Program studi PORKES dan Program Studi Kepelatihan Olahraga.

\section{DAFTAR PUSTAKA}

ARAZI, Hamid; COETZEE, Ben; ASADI, Abbas. Comparative effect of landand aquatic-based plyometric training on jumping ability and agility of young basketball players. South African Journal for Research in Sport, Physical Education and Recreation, 2012, 34.2: 1-14.

Azhar Arsyad. 2000. Media Pengajaran. Raja Grafindo Persada: Jakarta

CHAOUACHI, Anis, et al. Anthropometric, physiological and performance characteristics of elite team-handball players. Journal of sports sciences, 2009, 27.2: 151-157.

CHELLY, Mohamed Souhaiel, et al. Effects of 8-week in-season plyometric training on upper and lower limb performance of elite adolescent handball players. The Journal of Strength \& Conditioning Research, 2014, 28.5: 1401-1410.

Dale, Edgar. Audio-Visual Methods in Teaching, $3^{\text {rd }}$ ed., Holt, Rinehart \& Winston, New York, 1969, p.108

DUNCAN, M. J.; WOODFIELD, L.; ALNAKEEB, Y. Anthropometric and physiological characteristics of junior elite volleyball players. British journal of sports medicine, 2006, 40.7: 649-651.

Fathan Amirul Huda. 2019. Pengertian Media Pembelajaran. Diakses pada laman http://fatkhan.web.id/pengertian- media-pembelajaran/ pada 10 April 2020.

Lorena martin (2016). Sports Performance Measurement and Analytics: Anatomy and Physiology. Https://www.informit.com/articles/ar ticle.aspx? $\mathrm{P}=2481852$

STØLEN, Tomas, et al. Physiology of soccer. Sports medicine, 2005, 35.6: 501-536.

OSTOJIC, Sergej M.; MAZIC, Sanja; DIKIC, Nenad. Profiling in basketball: Physical and physiological characteristics of elite players. Journal of strength and Conditioning Research, 2006, 20.4: 740 .

-------.. Unesa. 2019. Dosen dituntut Membuat Buku Ajar sesuai Kebutuhan Mahasiswa. Workshop Penulisan Buku Ajar UNESA. Surabaya .., 2003. Media Pembelajaran, Departemen Pendidikan Nasional Direktorat Jenderal Pendidikan Dasar dan Menengah Direktorat Tenaga Kependidikan; Jakarta. 